much stimulate its activity, and if the exposare is a little prolonged the cells become much paler, the chlorophyll disappears, and the protoplasmic contents are more granular. The cells recover their green colour when exposed to sunlight, but on renewed exposure to $\mathrm{x}$ rays the chlorophyll seems to disappear more or less completely.

The following microscopic changes are to be noticed as the result of exposure of these bacilli prodigiosi to $x$ radiations. There is apparently little to call for notice as regards the relative size of the rayed and non-rayed bacilli. As regards groupirg, an unusual property of the bacillus prodigiosus was apparent-that is, growth in chains or strepto-bacteria ; and further, what is at present giving rise to controversy, spore formation, which seems to be clearly established by the presence of a chain preparation. For the rest, the bacilli appear in both cases equally granular and stain equally at the ends and as irregularly.

We are continuing these experiments, especially upon the pathogenic bacilli, among which it is possible that changes in growth may be accompanied with some alterations in the character of the bacilli.

\section{Cirnical a dotes:}

\section{MEDICAL, SURGICAL, OBSTETRICAL, AND THERAPEUTICAL.}

\section{NOTES ON A CASE OF PUERPERAL ECLAMPSIA OCCURRING IN THE SIXTH MONTH OF PREGNANCY ; DEATH.}

BY H. Howakd Murphy, M.D. Cantab,

ZHONORARY MEDICAL OFFICER TO ST. JOHN'S HOSPITAL, TWICKENHAM.

THE following notes on the case of a patient who was seized with puerperal eclampsia in the sixth month may be of interest to readers of THE LANCET in general as well as to "R. C.," who recently asked for references to cases."

On Oct. 21st, 1897, I was asked in the morning to call on a patient, about thirty years of age, who had vomiting and cramps in the stomach. She had one child, an easy confinement, four years ago, and was now some five months pregnant. She had not felt very well for some days, her stomach seeming to be out of order. There was no history of colic or janndice previously or of any serious illness, the patient being generally healtby. The attack commenced after breakfast by some colicky pains aross the upper abdomen and pains across the loins. She had rolled on the floor with pain, felt faint, and vomited once. The bowels were last - opened on the 19th, when they acted well twice. I ordered an enema, a mixture with tincture of chloroform and morphia, fomentations, appropriate diet, \&c. In the afternoon there was another attack of the colicky pain and the patient vomited twice. The tongue was clean; the liver - dulness was not increased; there was tenderness in the region of the epigastrium, but not over the gall-bladder, which could not be felt. The pulse was 75 and good and the temperature was normal. During the evening a second - enema had cansed a free evacuation; but the colic had been very severe and she had vomited frequently and all she took. There were no uterine symptoms at all. Morphia $\frac{1}{4}$ gr.) was injected hypodermically. She slept for four hours quietly; then she awoke and had severe colic and frequent vomiting and about 3 A.M. there occurred severe convulsions which lasted for an hour. Her pulse was 80 and good. Another hypodermic injection of morphia quieted her. At 10 A.M. she had two convulsions; she kept fairly conscious between the attacks; she complained much of epigastric pain and threw herself about and vomited frequently. She had passed very little urine, which contained a cloud of albumin. At noon she was distinctly jaundiced and was becoming less conscious. The temperature had risen to $100^{\circ} \mathrm{F}$. and the pulse was 80 and of fair strength. Dr. Amand Routh kindly saw the patient on the afternoon of the 22nd in consultation. He considered that the eclamptic state demanded the induction of labour and Inding that the os was patulous he was soon able to pass in

1 The LANCET, May 21st, 1898. a finger, to rupture the membranes, and to bring down a leg. There were no uterine contractions. He advised the continuance of the morphia and the administration of nutrient enemata with some bromide and chloral. In three hours the uterus was emptied and washed out. There were no more convulsions ; the patient was quieter, but she also gradually became less capable of being roused to answer questions or to take food. On the $23 \mathrm{rd}$ she had a quiet night, without convulsion, vomiting, or complaints of pain. She had not required any morphia. She recognised and spoke to me, answering questions. She passed no urine and no action - of the bowels rook place. The pulse was 100 and weaker. She took food well. All day she lay very quietly and in much the same condition. As no urine was passed by the evening the catheter was nsed and yielded $16 \mathrm{oz}$ of urine which was very dark coloured with bile and contained much albumin. The liver was terder and the area of dulness was diminished. The tongue was coated. The pulse went up to 120 and got weaker. She was very jaundiced. On the 24th the patient had passed a very quiet night. She took liquid nourishment well. No urine was passed. The bowels were frequently opened with small liquid motions. She had no convulsions and did not vomit. There was loss of vision and she said she could not see me but she recognised my voice; she was rambling and semiconscious. The pulse was 120 and very weak and the temperature was $100^{\circ}$. In the afternoon the catheter drew off $1 \frac{1}{2} \mathrm{oz}$. of urine which was very dark with bile and contained some blood. About 4 P.M. she became quite unconscious and very weak and died quietly in half an hour. No post-mortem examination was held.

Dr. Routh agreed with me that there was acute atrophy of the liver in this case as well as the eclampsia. The latter ceased as soon as the uterus was emptied, as did the epigastric pain and romiting. The urine contained albumin, was scanty, and almost suppressed at last.

Twickenham.

\section{A CASE OF CONCEALMENT OF BIRTH.}

By Sanderson Møllok, L.R.C.P., L.R.C.S. Edin, L IF.P.S. GLASG.

THE following is a curious and interesting case as showing what can be done by one who has just given birth to a child.

A single woman, aged twenty-three Jears, lived with her father (who is a widower) and a sister, aged fifteen years. The mother died some years ago and the home surroundings and comforts of these two daughters had not been of the happiest. The elder sister, whose extraordinary conduct I am referring to, gave birth to a child about two years ago and I understand she was on that occasion attended by a midwife. She expected her second confinement last February. For some reason-most probably shame-she never mentioned her condition to anyone and for a month or six weeks before the event she kept to the house and was never seen outside, not even by the next door neighbours. At 12.30 P.M. on the day on which she was confined she told her sister that she was in pain and asked her to fetch her married sister who lived two and a half miles away. This sister was, however, unable to go as her children were all ill and she could not leave them. The young girl then ran nearly two miles for another sister, with the result that the second sister went at once. She arrived at her father's cottage at $330 \mathrm{P} . \mathrm{M}$. and finding the back door locked she ran round to the front and there met the girl who had just been confined. She then told her sister that she had had a "loss" and that she had put it in the water-closet. The girl was immediately put to bed and a neighbour was called and a close inspection of the water-closet revealed nothing which threw any light on this mysterious affair. The floor near the bed, the bedclothes, and the girl's linen were all soaked in blood. In the centre of another room and on the floor was a dirty old bag which had been used for stopping up the chimney, and in this bag, in which there was a large quantity of horsehair, a fully developed after.birth was found. Up the chimney in the same room another dirty bag was discovered which contained the body of a fall-time child. The matter was placed in the hands of the police and I made a postmortem examination. The umbilical cord was one yard long and was coiled round the child's neck, and the cord 
was torn about 6 in. from the placental end. The child had breathed.

This case is interesting inasmuch as barely three hours had elapsed from the time labour had commenced to the time the concealment of the birth was bronght to light. Although the mother must have lost an enormons amount of blood, as evidenced by the state of the room and her linen, and notwithstanding the fact that she was removed to the union the next morning, a distance of two miles, she is now quite well.

West Malling, Kent.

\section{A CASE OF GUMMA INSIDE THE STERNUM.}

By Thomas Cole, M.D., F. R.C.P.Lond.,

IATE SENIOR PHYSICIAN TO THE ROYAL UNITED HOSPITAI, BATH.

I WAS a few years ago asked by his two medical attendants to see a man, aged about forty-eight years. He had been indefinitely ill for some time, suffering from dyspncea, slight congh, and some blueness. The most minute examination of every organ revealed nothing, but I found on the front of the sternum a small boss or elevation which was a third of an inch wide and about the same in elevation. The mass was slightly tender. I was the first to discover it. I also thought the substernal respiration was somewhat more tracheal than usual. Taking the few facts into consideration I suggested that there might be some gummatous mischief and advised the administration of $20 \mathrm{gr}$. of iodide of potassinm every four hours. But I could make no impression on my friends, who would express no opinion, and only (when I was gone) put eight leeches over the little swelling. In two or three days we met again. The mass was rather larger, there was a little more dyspncea, the respiration was noisy, and there was a slight laryngeal congh I still urged my plan; it could do no harm and might confer immense benefit on the patient, whose case I began to think of with great distrust. Bat I could not move these practitioners by any argument whatever. Still they believed in me and on many occasions had called me in. They wished me to meet them again in a week, which of course I did. The poor fellow was evidently gradually slipping through their fingers; every symptom was worse, intra-sternal pressure was more marked, and renous stasis above the clavicles was developing. I asked, "Are you prepared to go on treating this case as you are-doing nothing?" One of them said, "Are you prepared to give us a good reason for such heroic treatment as the administration of $20 \mathrm{gr}$. of jodide of potassinm every two or three hours" (which I then proposed)? A merciful providence intervened on the patient's behalf as well as on my own. Strange, indeed, was it that the left sleeve of his night-dress being unbuttoned and drawn up towards the elbow I saw a large node on the ulna at least $2 \frac{1}{2}$ in. by $1 \frac{1}{2}$ in. I pointed it out to my sceptical friends and turning to the patient said: "How long have you found this?" "It was not there, Dr. Cole, when you last came, but the day after it began to come and it is getting very painful. I intended to call your attention to it this morning as I knew you were all coming and you had asked about swellings before." Persuasion leaped into the minds of my friends after so nnmistakeable a proof of the nature of the malady and the treatment was at once begun. In a very short time all the evidence vanished and the patient resumed his usual health. Of course, he was most carefully watched and when I heard of his state a year afterwards he was well and free from disease. Does not such a case prove to every practitioner the absolnte necessity of an accurate diagnosis in every case which comes under his notice? How many lives would be saved were common care taken in such important and critical matters?

Bath.

\section{NOTES ON TWO CASES OF CONGENITAL ABSENCE} OF THE RIGHT EYE (ANOPHTHALMOS).

By John R. Rolston, L.R.C.P. EpIn., M.R.C.S. ENG , GURGHON TO THE ROYAL EYE INFIRMART, PLYMOUTH, AND OPHTHALMIO SURGBON TO THE ROYAL ALBERT HOSPITAL, DEVONPORT.

IN THe LANCET of Jan. 1st, 1898, Mr. W. G. Nash of Bedford records a case of Congenital Absence of the Right Wye, with an illustration. As I have seen two cases of the same deformity-one of which very closely resembles the case related by Mr. Nash-I thought an account of them would interest the readers of TII LANCET. The accom panying illustration is reproduced from a photograph of thes one which is so similar to that described by Mr. Nash.

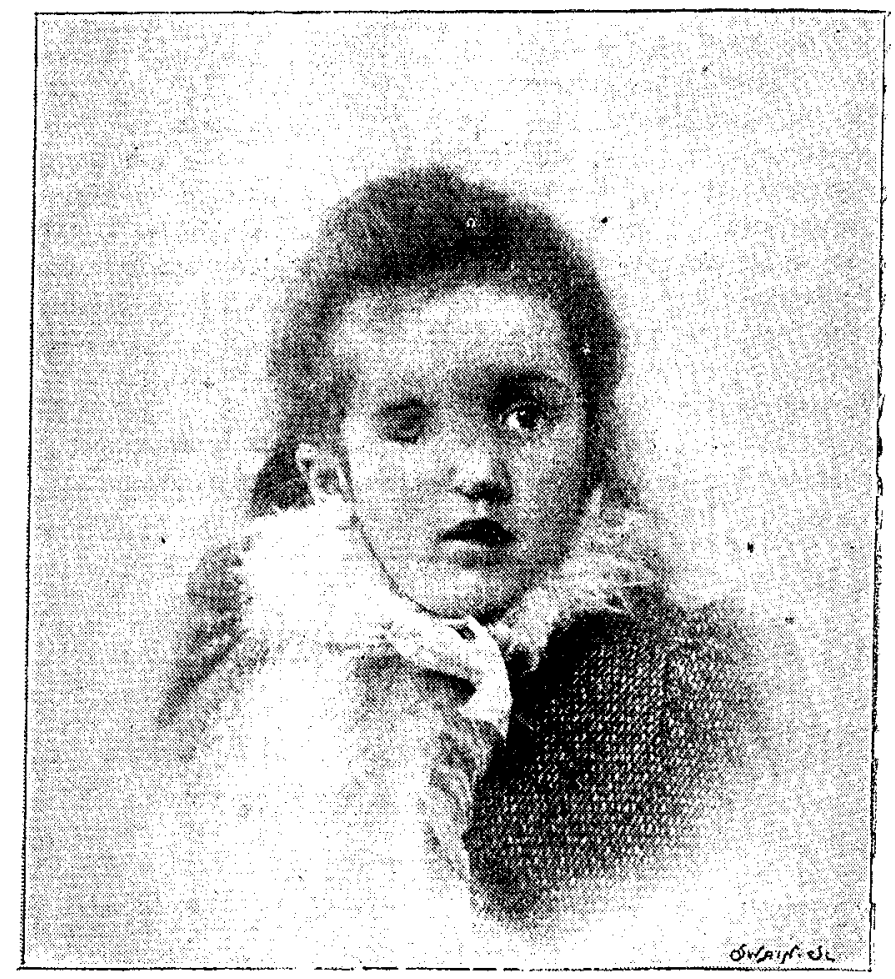

Portrait of the patient (aged six years) in Case 1.

CASE 1.-A girl, aged six years, was brought to me in December, 1896. There was-as is depicted in the illustration-congenital absence of the right globe with a smals rudimentary palpebral aperture $12 \mathrm{~mm}$. long with eyelashes; a small carancle was seen inside. No evidence of a rudimentary globe was observed. There was much flattening of the bridge of the nose and the right ala of the nose was imperfectly developed. The left eye had horizontal nystagmus. The mother has had 5 children, all of whom are healthy. She has had no miscarrlage. She says that she had a fall several months before the child was born.

CAsE 2.-A girl, aged six years, was brought to me in December, 1896. There was congenital absence of the right eye with a small but otherwise natural palpebral aperture $19 \mathrm{~mm}$. long. The cavity seemed to be natural. There was no sign of a rudimentary globe. No defect of the face was present. In this case the mother was not seen by me and no family history could be obtained. Photography was not allowed. The left eye was normal.

I am of opinion that these two cases may be correctly classified as true anophthalmos, as in each case I failed to find any rudimentary globe (although I did not use dissection), and this class is much more rare than that to which should imagine Mr. Nash's belongs- - iz., that of microphthalmos, as he states that "a small pigmented body about. the size of a pea occupied the centre of the cavity" of the orbit. The point in common is that in all three cases the right side is affected.

Plymouth.

\section{NOTE ON A CASE OF FATAL HEART AFFECTION IN SCARLATINAL RHEUMATISM.}

By Frank RoBINSON, M.D. VICT.,

RHSIDENT MEDICAI OTFICER, CITY HOSPITAL NORTH, LIVERPOOZ.

I BELIEVE that the following case of acute pericarditis (largely obliterative) will be of interest in connexion with the: annotation on obliterative pericarditis in THH LANCET of June 18tb, 1898.

A girl, aged ten years, suffered from an attack of scarlet. fever of average severity in the City Hospital North, Liverpool, and made a satisfactory recovery from the acute stage. On the twenty-first day a mild attack of articulaz rheumatism commenced. There was no local swelling and but little pyrexia occurred, but the wandering pains persisted and on the fiftieth day severe pain drew special attention to the hort. An extensive area of pericardial 